\title{
How to Balance the Flexible Norm and Lex Certa in Environmental Offenses?
}

\author{
Mahrus Ali \\ \{mahrus_ali@uii.ac.id\} \\ Faculty of Law, Universitas Islam Indonesia, Indonesia
}

\begin{abstract}
Environmental offenses are generally formulated in an abstract and flexible way because they refer to the norms that have yet to be formulated by other administrative organs who have authority in the environmental sector. The formulation of such offenses is of course contrary to the principle of lex certa which requires that the offense must be formulated clearly and does not have multiple interpretations. With a clear formulation of offenses, individuals can easily understand offenses so they know the consequences if they break them. This article is specifically examined at how to balance the flexibility of norms and clarity of norms in the formulation of environmental offenses. The results of the research revealed that the formulation of environmental offenses that reflects this balance is to putting the core elements of offense in the Act and to leave the technical matters of offense in a government regulation. Even though on these technical matters, administrative officials are given the authority to determine whether or not there is a criminal act based on discretionary authority, this must not violate the principle of rationality and proportionality so that it still reflects a clarity of norms (the principle of legal certainty). An offense formula that is deemed unclear will become clear with science. The clarity of a legal norm is not only based on its formulation, but shifts to the underlying principle of justice.
\end{abstract}

Keywords: Flexible norm; Lex certa, Environmental offenses; Principle of justice

\section{Introduction}

As a law-based state, or 'rechtstaat' in the civil law tradition and 'rule of law' in the common law tradition, Stahl argued that four elements should be included to meet rechtstaat requirement, namely human rights, separation or distribution of power, government based on regulations, and administrative judiciary in disputes [1]. The mandate of Article 1 paragraph (3) and Article 23A of the 1945 Constitution of the Republic of Indonesia in several tax laws and other binding levies are still not compatible with the three legal values which, according to Gustav Radbruch, consist of legal certainty, public benefit, and justice. This fact shows that there are still many disputes over taxes, customs and excise, and local taxes and levies that tax courts in Indonesia must handle. Table 1 summarizes the number of disputes according to the respondent/defendant during 2014-2020, which has reached 86,349 dispute files, while Table 2 summarizes the settlement of tax disputes in 2014-2020, which has reached 72,314 disputes [1].

The mandate of the 1945 Constitution of the Republic of Indonesia is that any tax collection and other compelling levies must be based on law. However, in the implementation, various objections and disputes still occur in appeals and lawsuits, in which the settlement 
must be based on law. However, the meaning of legal settlement does not refer to the existence of an independent judicial body but to the settlement of any objections and/or disputes of tax and other compelling levies which occurs in several bodies, including several bodies under the executive power that make the rules, regulations, orders, and decisions of the state administration, as well as several bodies under the jurisdiction of the judiciary.

Of course, things like this are what worries Hart and Cushman. Hart stated that there should be areas that the judicial power must handle. Those who create administrative discretion and at the same time defend the implementation of decision-making by employees through the control of the executive power should not regulate implementation [1]. The policy of decision-making on administrative authority must be continued with the distribution of power, one of which is to give authority to the courts in controlling the rules, regulations, orders, and decisions of the state administration against anyone who seeks to look for justice for every legal action of the state administration. This must be handled with the need for mutual control between one institution and another. Just as every institution involved in objections, appeals and lawsuits, they have the right to supervise the progress of the ongoing process with every step being monitored [1].

Therefore, it is necessary and urgent to resolve the issue of a dualism of authority in handling objections and/or disputes (in the form of appeals and lawsuits) of taxes and other levies, considering that there have been many thoughts suggesting to avoid the dualism of authority. Wan Juli and Joko Nur Sariono recommended reforming an exclusive, transparent, and accountable tax court based on simple, fast, and inexpensive court. This is related to the existence of several things. Firstly, it can relate to the rights and obligations of the taxpayer in an appeal and lawsuits, in some cases, being unprotected. Secondly, it can relate to the limitation of absolute competence resulting in the taxpayer's application being unable to be considered or not further processed. Sometimes, it can also relate to different procedural laws than the Administrative Court Procedure Law, which creates confusion and uncertainty because dispute resolution efforts at the Tax Court are very exclusive to the PTUN [1].

Of course, efforts to address problems in objections, appeals, and suits on tax and other compelling levies must be carried out philosophically and juridically by exploring the root of the problem based on the existence of philosophical gaps, juridical gaps, and empirical gaps. This philosophical gap can be seen from the following two main points. First, the collection of taxes and other compelling levies that must be based on the law has made the text of the law very sacred rather than interpreted it, as if the certainty of statutory regulations is legal certainty [1]. Second, the understanding that considers that dispute on tax and other compelling levies is an effort to obtain justice for each disputing party in administrative law due to the characteristics and features of the tax collection system (and other compelling levies) [1].

The juridical gap can be seen from differences in understanding of interrelated laws but always highlight the respective supremacy of official state institutions. First, the existence of Article 10 and Article 13 of Law Number 48 of 2009 concerning Judicial power (Law on Justice) has formulated the existence of four judicial environments, namely the General Court, the Religious Court, the Military Court, and the State Administrative Court. It is possible to form a special court in the form of Law Concerning Courts, as it appeared in the Tax Court Law.

Second, Article 2 of Law Number 14 of 2002 concerning the Tax Court (Tax Court Law) confirms that the tax court is a judicial body that exercises judicial power to resolve tax disputes. However, it does not limitedly determine the function of the Tax Court as stated in Article 17 paragraph (1) of the Judiciary Law. Instead, it only functions as an explanation of 
Article 27 paragraph (1) of the Judiciary Law which states that Tax Court is a special court in the Administrative Court so that it causes the Tax Court and PTUN to have certain similarities, among others are (a) subjectumlitis which is civil society as the party in the case and government officials as defendants; (b) objectum litis decision (beschikking); c) both the Tax Court and PTUN have a similar function to verify the validity (rechtmatigheid) of the government's treatment [1].

Third, the Tax Court Law does not reflect the independence of the judiciary as mentioned in Article 24 paragraph (1) of the 1945 Constitution and Judiciary Law. This can be seen from the guidance of the Supreme Court and the Ministry of Finance as stipulated in Article 5 paragraph (1) and (2) of the law. Besides, the Ministry of Finance's very broad authority regarding the Tax Court can affect the principle of independence. Fourth, Article 5 of Law Number 30 of 2014 concerning Government Administration (Government Administration Law) has formulated that the execution of government administration must be based on legality principles, principles of protection of human rights (HAM), and General Principles of Good Governance (AUPB).

This article must be a guarantee that public services are carried out and can achieve maximum results in the execution of government administration. Furthermore, this AUPB has been recognized in a statutory framework. It refers to Law Number 51 of 2009 concerning the Second Amendment to Law Number 5 of 1986 concerning State Administrative Courts (PTUN Law) as in Article 53 paragraph (1) and (2). Also, it is along with an explanation which states that a person or civil legal entity who feels that a State Administrative Decree has harmed his interests can file a written lawsuit to the competent court containing demands that the disputed State Administrative Decree be declared null and void, with or without a claim for compensation and/or rehabilitation.

It is important and urgent to resolve the dualism of resolving objections, appeals, and suits on taxes and other compelling levies. The fact shows that there are still philosophical gaps, juridical gaps, and empirical gaps in objections, appeals and suits on tax and other compelling levies, and the need to implement justice and the principle of checks and balances against all parties involved in objections, appeals, and suits on tax and other compelling levies.

\section{Research Methods}

This research method is a normative method called the doctrinal method by Soetandyo Wignjosoebroto. Legal research with the doctrinal method still occupies a central position in writing carried out by legal professionals. Alexander Peczenik has put forward the adequacy of the doctrinal method by stating that the constituent components are normative components as well as moral and other substantive considerations that are interrelated. This produces coherence in many aspects of law, such as aspects of using traditional methods, aspects of systematization, aspects of overarching principles of law, aspects of unity in time, and aspects of legal validity [1].

Furthermore, Soetandyo Wignjosoebroto argues that this method is research on the law conceptualized and developed based on the doctrines adhered to by the drafter and developers. It must be understood that law in its large category as a norm must reach into two subcategories, namely meta-juridical legal norms (such as justice, propriety, or national morals) and positive norms (such as rules of laws). Thus, this study is consistent with its normative 
method, which examines meta-juridical legal norms and positive norms to answer the formulated problems [1].

\section{Results and Discussion}

A tax dispute, as stated earlier, involves a person or entity as a taxpayer or a tax bearer dealing with a competent official. Thus, in a tax dispute, a person or entity is dealing with an authorized official on the other. The definition of a person, in this case, is a person who has the position of supporting certain taxation rights and obligations. There is no explanation in the law regarding this taxpayer. Therefore, it is based on the provisions of the taxation law concerned. For example, for disputes related to income tax, taxpayers refer to Law Number 7 of 1983 as amended several times, most recently by Law Number 36 of 2008 concerning Income Tax. Apart from people in a tax dispute, an entity can also file a lawsuit or appeal. In this case, it is not stated whether what is meant by an entity must be a legal entity such as a limited company, foundation or cooperative.

Therefore, when referring to various laws and regulations in the field of tax, presumably what is meant by an entity is not necessarily a legal entity. A firm, joint venture, limited partnership, and so on can file a lawsuit or appeal. Of course, it is the organs of that entity that file an appeal or lawsuit. This is because, according to the statutes and by-laws, they are appointed as the parties that have the right to represent the company, both outward and inward.

Law No. 14 of 2002 does not explicitly regulate the general grounds for filing an appeal, even though one of the conditions for filing an appeal and lawsuit is that the plaintiff must state clear reasons regarding the basis of the lawsuit. This means that submissions that are not accompanied by clear reasons must be rejected. Taxpayers are faced with the power and authority of the Directorate General of Taxes deciding whether their lawsuit will be granted in whole or in part or rejected (article 26 paragraph 3 of the KUP Law). The decision is not on the authority and power of the Tax Court judge who resolves tax disputes following the Tax Court Law. With this dualism, it becomes a fundamental question why the objections at the Directorate General of Taxes were rejected, but at the appeal level, most of the objections were accepted by the Tax Court. The objection on tax handled outside the tax court is a door open to the occurrence of "case brokers" and bribery because the supervision for this case is not regulated.

To make decisions that truly create legal certainty and reflect justice, judges as state apparatuses who carry out the judiciary must know the actual sit of the case and the legal regulations governing it, either legal regulations written in statutory regulations or unwritten laws such as customary law. Therefore, in the Law on Judicial Power, it is stated that judges are obliged to explore, follow, and understand the values of law and the sense of justice that live in society.

There are two possibilities for deciding: consensus or based on majority votes, and no third possibility. If the panel in deciding by deliberation does not reach an agreement so that a majority vote makes the decision, the opinion of the judge members who do not agree with the decision shall be stated in the Tax Court's decision (dissenting opinion). The elucidation of the law stated that the inclusion of different opinion of judge members in the tax tribunal decision is intended so that disputing parties can know the situation and considerations of judge members in the panel. 
Furthermore, a judge power or a judge's decision has several principles that should be upheld in every decision, such as in Law No.4 of 2004 concerning Judicial Power. Husein Kartasasmita suggested that dispute resolution through objections should be abolished. That is, on the tax assessment, direct taxpayers can file an appeal. The reasons put forward include that, in general, the objection letters submitted to the Director-General of Taxes only result in rejection after the taxpayer has waited for 12 months [1]. A similar opinion was expressed in an article in Indonesia Tax Review, which proposed eliminating the objection process [1].

This concerns independence, and the objection process will only prolong the tax dispute settlement process. Both opinions doubt the settlement of tax disputes by the parties involved in the dispute, and in this case, the parties are the Director-General of Taxes. This doubt questions the guarantee of legal protection for the rights of taxpayers. This means that there are doubts about the attitude of the Director-General of Taxes whether he can act fairly in the process of resolving tax disputes through objections.

The opinion above is logically acceptable if it is viewed from the involvement of the disputing parties in the dispute resolution process as the decision-maker of the taxpayer's objection case. So, the fairness side of the decision may be mixed with the interests of the tax apparatus. As a result, the taxpayer's objection will be felt to be not optimal if the party being objected still has the authority to decide the taxpayer's objection.

In the settlement of tax disputes, it is concluded that the judge is obliged to convey a written consideration or opinion regarding the case being examined, and the file becomes an integral part of the decision. Such provisions are stipulated so that no judge does not submit his opinion in drafting a decision. This means that only one or two members cannot decide of the panel of judges, and other members just follow and submit. This is considered important because the decision on a case is a legal decision made by the panel of judges collectively, not individually. It is necessary to stipulate clearer legal provisions not to create different interpretations. These legal provisions will provide certainty, not cause doubts in their implementation. In addition, the possibility of provisions contradicting with another can be avoided so that taxpayers will be guaranteed a more certain legal protection for their rights.

The authority for the settlement of tax disputes by the Director-General of Taxes is delegated to the Head of the Regional Office of the Directorate General of Taxes (Kakanwil) in the regions. And then, part of the authority is delegated to each Head of KPP under the Regional Office of the Directorate General of Taxes by following the policies of each Kakanwil. The delegation of authority to settle tax disputes is expected to accelerate the settlement process for each taxpayer. In the KUP Law, the arrangements for settling tax disputes by the Directorate General of Taxes and the Tax Court are regulated in several different chapters. Article 16 of KUP Law or the cancellation of incorrect tax assessment.

According to the author, the Tax Court is not integrated under the Supreme Court. This is contrary to the Law on Judicial Power which mandates a single court under the Supreme Court. The Supreme Court's power is limited to the technical guidance of the judiciary (Article 5 paragraph 1 of the Tax Court Law). At the same time, the affairs of organizational, administrative, and financial development are carried out by the Department of Finance, which is now the Ministry of Finance (Article 5 paragraph 2). The position of the Tax Court is under the Ministry of Finance, which will weaken the supervisory function and independence of judges in the Tax Court. So that the circle and practice of the case mafia in the Tax Court are difficult to decide because it is difficult for the Supreme Court and other external supervision to go further into the tax court system. 


\section{Conclusion}

Reformulation of objections, appeals, and suits on tax and other compelling levies in Indonesia in the legal remedy that can be made against the and tax court's decision on appeals or suits is a judicial review to the Supreme Court. Law no. 14/2002 concerning the Tax Court does not adhere to principles and contradicts Article 24 of the 1945 Constitution Third Amendment. Law no. 48 of 2009 concerning judicial power reflected the placement of the Tax Court as a pure administrative court so that the position of the tax court in the judicial system in Indonesia is not following the judicial power structure, which requires a unitary judicial system because the tax court is the court of the first and last level in examining and deciding tax disputes.

The relative competence of the Tax Court covers the entire jurisdiction of the Republic of Indonesia so that the principles of tax dispute resolution, such as the principles of speed, simplicity, and low cost, are not beneficial to the disputing parties. Tax officials and taxpayers who play a role in legal protection in the settlement of tax disputes have not benefited the state, including the parties in dispute. There is still a tax compromise between tax officials and taxpayers which in essence is an act of violation of the law.

\section{References}

[1] Budiardjo Miriam, (2008) Dasar-Dasar Ilmu Politik, Jakarta: Penerbit PT. Gramedia Pustaka Utama.

[2] Cole, Kenneth C. (1938), Some Recent Proposals in the Sphere of Administrative Justice, The American Political Science Review, Vol. 32, No. 5.

[3] Indonesia Tax Review (2002) Volume 1 Edisi 13.

[4] Juli Wan \& Joko Nur Sariono, (2014) Hak dan Kewajiban Wajib Pajak dalam Penyelesaian Sengketa Perpajakan di Pengadilan Pajak, Perspektif, Vol. XIX, No. 3.

[5] Kartasasmita, Hussen (1984) Penjelasan dan Komentar Pajak Pengasilan, Jakarta: Yayasan Bina Pajak.

[6] Olsson, Stefan (2009) Defending the Rule of Law in Emergencies Through Checks and Balances, Democracy and Security, Vol. 5, No. 2.

[7] Peczenik, Aleksander. (2004) Can Philosophy Help Legal Doctrine, Ratio Juris, Vol. 17, No.1.

[8] Rahardjo, Satjipto Hukum Progresif: Sebuah Sintesa Hukum Indonesia, Yogyakarta: Genta Publishing.

[9] Sekretariat Pengadilan Pajak Kementerian Keuangan, 2020, "Statistik", available in http://www.setpp.kemenkeu.go.id/statistik, accessed on 13 Maret 2021.

[10] Sinaga, Benny R. P., et al. (2020) Justice Reconception In Establishing Responsive Tax Law in Indonesia: A Rawlsian Perspective. Ayer Journal, Vol. 27, No. 3.

[11] Suhartono, Slamet dan Mokhamad Khoirul Huda (2019) The Exsistence of Tax Court in Indonesia Judicial System, Journal of Advanced Research in Law and Economics, Vol. IX, Issue 3 (41). 